Brit. J. soc. Med. (1947), 1, 33-50.

\title{
EPIDEMIOLOGY OF INFECTIVE HEPATITIS AMONG ALLIED TROOPS IN ITALY
}

\author{
BY \\ P. L. MCKINLAY, M.D., D.P.H. \\ AND \\ SIDNEY C. TRUELOVE, M.A., M.D.
}

(Received December 30, 1945)

For infective hepatitis we have not, as for most other important diseases, an extensive peace-time background of knowledge as a directive to the most profitable lines of study. The aim of this field inquiry among troops in Italy has been to obtain accurate knowledge of the influence of such circumstances as: (a) age; (b) previous attacks; (c) length of service in areas of high prevalence; $(d)$ other agencies such as methods of feeding, sanitation, and overcrowding.

A problem with so many variables worthy of investigation ideally demands the simplest epidemiological set-up available. This implies a static or semi-static population, for which the following information is accessible: (i) relevant particulars (e.g., age, length of service, rank) of all individuals in the group, including immigrants and emigrants; (ii) dates of entrance and exit of members of the group; (iii) particulars of intragroup differences with respect to external circumstances or habit of life.

Prima facie, base units would commend themselves for study with these considerations in view; and experience of the previous year, when infective hepatitis was prevalent in base as in forward units, encouraged us to undertake extensive preparations to provide background data from base units in the area. Low incidence of the disease frustrated this plan. Accordingly, it was necessary to concentrate attention on forward troops. We therefore chose New Zealand and Canadian units, because they were subject to massive epidemics at the time. Inescapably, therefore, the inquiry was beset by difficulties arising from rapidly fluctuating location and population structure of the social group.

In its preliminary stages the need for two classes of information not mentioned hitherto became evident: (a) prevalence of infective hepatitis in the indigenous population, especially in view of reports to the effect that Italian troops had suffered heavily from the disease in the Western Desert; $(b)$ concomitant features of jaundice among syphilitics undergoing arsenical treatment, especially in view of emergent indications of its infective nature and of its spread by contaminated syringes. 


\section{Infective HePatitis among New ZeAland Troops}

For New Zealand troops available information relevant to our aim refers only to hospital admissions. In conformity with N.Z. Army medical regulations in force, these included all cases diagnosed as infective hepatitis, some being subicteric. Table I, which refers to 2 nd N.Z.E.F., cites relative admission rates to hospital for the period mid-1942 to the end of 1944, and indicates the importance of infective hepatitis as a major problem of war medicine. Since infective hepatitis causes prolonged incapacity, such admission rates do not exaggerate its contribution to total wastage.

TABLE I

Showing the Relative Importance of Infective Hepatitis and Certain Selected Causes of Hospital Admission (2 N.Z.E.F.)

\begin{tabular}{|c|c|c|c|c|c|c|c|c|}
\hline & $\begin{array}{l}\text { Infective } \\
\text { Hepatitis }\end{array}$ & Malaria & Enteric & Dysentery & Diarrhoea & V.D. & $\begin{array}{c}\text { Battle } \\
\text { Casual- } \\
\text { ties }\end{array}$ & $\begin{array}{l}\text { Acci- } \\
\text { dents }\end{array}$ \\
\hline $\begin{array}{cl}1942 & \text { Jul.- } \\
\text { 19343 } & \text { Oct.- } \\
\text { Jan.- } \\
\text { ” } & \text { Apr.- } \\
\text { ” } & \text { Jul.- } \\
\text { 19̈44 } & \text { Oct.- } \\
\text { Jan.- } \\
\text { ” } & \text { Apr.- } \\
\text { ” } & \text { Jul.- } \\
\text { ” } & \text { Oct.-Dec. }\end{array}$ & $\begin{array}{r}1 \cdot 48 \\
21 \cdot 92 \\
2 \cdot 80 \\
1 \cdot 06 \\
1 \cdot 72 \\
3 \cdot 20 \\
6 \cdot 15 \\
2 \cdot 48 \\
11 \cdot 15 \\
14 \cdot 55\end{array}$ & $\begin{array}{l}3.79 \\
1.71 \\
1.39 \\
1.65 \\
1.86 \\
1.98 \\
0.26 \\
0.41 \\
2.04 \\
0.53\end{array}$ & $\begin{array}{l}0.04 \\
0.12 \\
0.07 \\
0.02 \\
0.97 \\
0.95 \\
0.07 \\
0.19 \\
0.15 \\
0.07\end{array}$ & $\begin{array}{r}6 \cdot 26 \\
3 \cdot 59 \\
2 \cdot 28 \\
5 \cdot 67 \\
11 \cdot 76 \\
4 \cdot 94 \\
1 \cdot 20 \\
4 \cdot 18 \\
3 \cdot 26 \\
1 \cdot 96\end{array}$ & $\begin{array}{l}7 \cdot 47 \\
2 \cdot 43 \\
1 \cdot 78 \\
4 \cdot 68 \\
4 \cdot 73 \\
3 \cdot 70 \\
2 \cdot 67 \\
4 \cdot 11 \\
5 \cdot 48 \\
3 \cdot 03\end{array}$ & $\begin{array}{l}1.35 \\
2.05 \\
1.94 \\
2.06 \\
1.91 \\
1.64 \\
2.16 \\
5.38 \\
3.80 \\
3.45\end{array}$ & $\begin{array}{r}17 \cdot 95 \\
16 \cdot 71 \\
11 \cdot 33 \\
12 \cdot 89 \\
0 \cdot 00 \\
15 \cdot 28 \\
16 \cdot 28 \\
8 \cdot 45 \\
14 \cdot 35 \\
11 \cdot 15\end{array}$ & $\begin{array}{r}6 \cdot 88 \\
7 \cdot 07 \\
13 \cdot 07 \\
12 \cdot 60 \\
11 \cdot 63 \\
15 \cdot 75 \\
13 \cdot 17 \\
12 \cdot 80 \\
10 \cdot 19 \\
9 \cdot 36\end{array}$ \\
\hline $\begin{array}{c}\text { Jul., 1942-Dec., } \\
1944 \quad \ldots\end{array}$ & $7 \cdot 19$ & $1 \cdot 73$ & $0 \cdot 24$ & $4 \cdot 57$ & $4 \cdot 28$ & $2 \cdot 54$ & $13 \cdot 01$ & $10 \cdot 63$ \\
\hline
\end{tabular}

The New Zealand data have three advantages for our purpose: (i) the Expeditionary Force maintained in the field an admirable system of medical documentation covering all admissions to medical units; (ii) the troops were made up of reinforcement groups that had arrived in the Mediterranean zone at widely separated times, precise details of which were available: hence length of service in the zone was known for each reinforcement group; (iii) during a rest period in the middle of the epidemic the division chosen was able to carry out a complete census of rank, age, unit and reinforcement group.

Fig. 1 discloses the seasonal picture, which conforms to general experiencei.e., that epidemics of infective hepatitis occur in autumn and winter. The regularity of the configuration there shown conceals differences regarding the magnitude and timing of epidemic peaks in individual units within the total force. Comparison of the experience of individual units yielded no evidence that the 
magnitude of an epidemic is closely associated with time of occurrence. Table II shows the date of onset of the median case in each divisional group during the

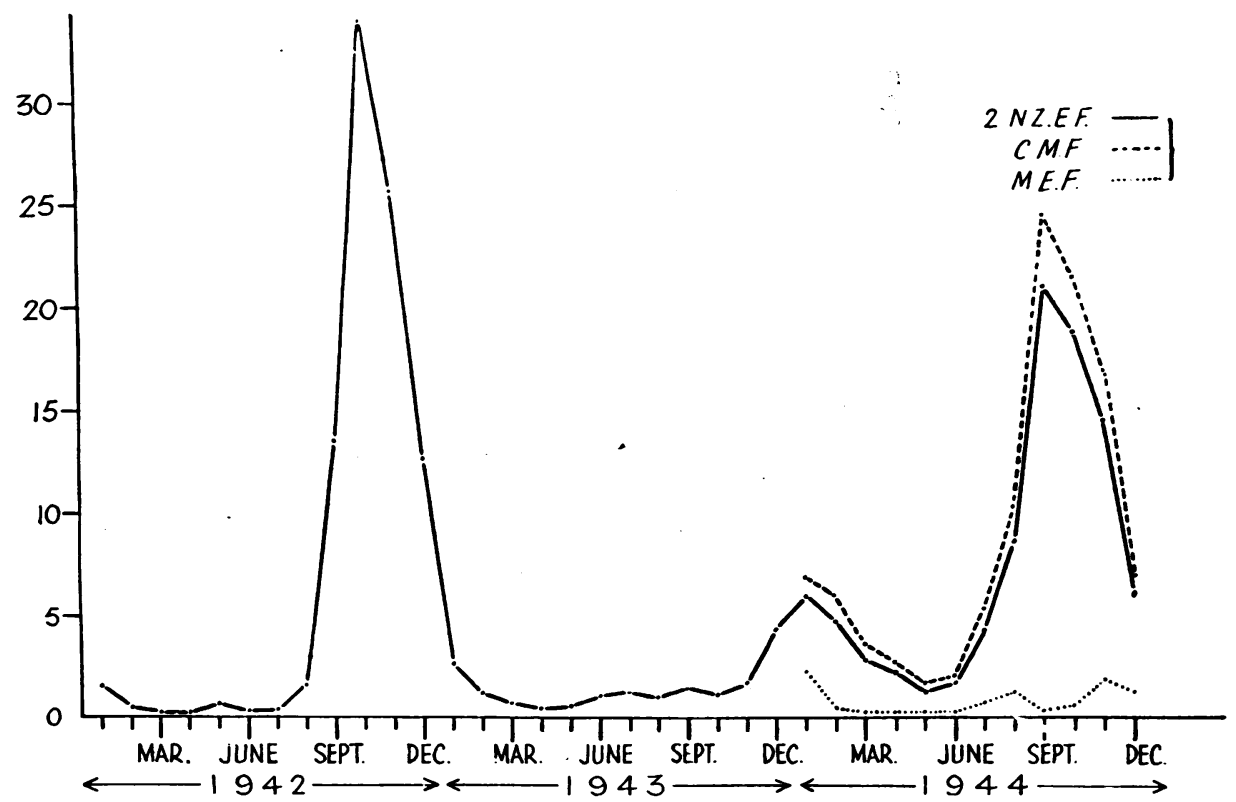

Fig. 1.-Crude rates per 1,000 population (2 N.Z.E.F.) monthly for 1942-44.

full epidemic of 1944, together with corresponding dates for upper and lower quartiles. The semi-interquartile range (extreme right-hand column) may be taken as an index of the total duration of a group epidemic.

TABLE II

Showing Quartile Values for Divisional Groups (2 N.Z. Div.)

\begin{tabular}{|c|c|c|c|c|c|c|}
\hline & & & Median & Lower Quartile & Upper Quartile & $\frac{Q_{3}-Q_{1}}{2}$ \\
\hline $\begin{array}{l}\text { Infantry } \\
\text { Armoured } \\
\text { Engineers } \\
\text { Artillery } \\
\text { Medical } \\
\text { Workshops } \\
\text { H.Q.s . } \\
\text { A.S.C. } \\
\text { Remainder }\end{array}$ & $\begin{array}{l}. . \\
\cdots \\
\cdots \\
\cdots \\
\cdots \\
\cdots \\
\cdots \\
\cdots\end{array}$ & \begin{tabular}{l|}
. \\
. \\
. \\
. \\
. \\
$\cdots$ \\
. \\
. \\
.
\end{tabular} & $\begin{array}{r}23 / 9 / 44 \\
17 / 10 / 44 \\
29 / 9 / 44 \\
9 / 10 / 44 \\
21 / 9 / 44 \\
29 / 9 / 44 \\
25 / 9 / 44 \\
14 / 10 / 44 \\
5 / 10 / 44\end{array}$ & $\begin{array}{r}29 / 8 / 44 \\
19 / 9 / 44 \\
9 / 9 / 44 \\
14 / 9 / 44 \\
29 / 8 / 44 \\
29 / 8 / 44 \\
31 / 8 / 44 \\
19 / 9 / 44 \\
8 / 9 / 44\end{array}$ & $\begin{array}{r}20 / 10 / 44 \\
14 / 11 / 44 \\
18 / 10 / 44 \\
8 / 11 / 44 \\
10 / 10 / 44 \\
2 / 11 / 44 \\
23 / 10 / 44 \\
17 / 11 / 44 \\
8 / 11 / 44\end{array}$ & $\begin{array}{l}26 \cdot 0 \\
28 \cdot 0 \\
19 \cdot 5 \\
27 \cdot 5 \\
21 \cdot 0 \\
32 \cdot 5 \\
26 \cdot 5 \\
29 \cdot 5 \\
30 \cdot 5\end{array}$ \\
\hline Total & . & .. & $31 / 9 / 44$ & $7 / 9 / 44$ & $31 / 10 / 44$ & $27 \cdot 0$ \\
\hline
\end{tabular}


Over the entire period of the 1944 epidemic the proportional incidence in each of four main age groups (20-24, 25-29, 3034 , and over 35 years) remained constant

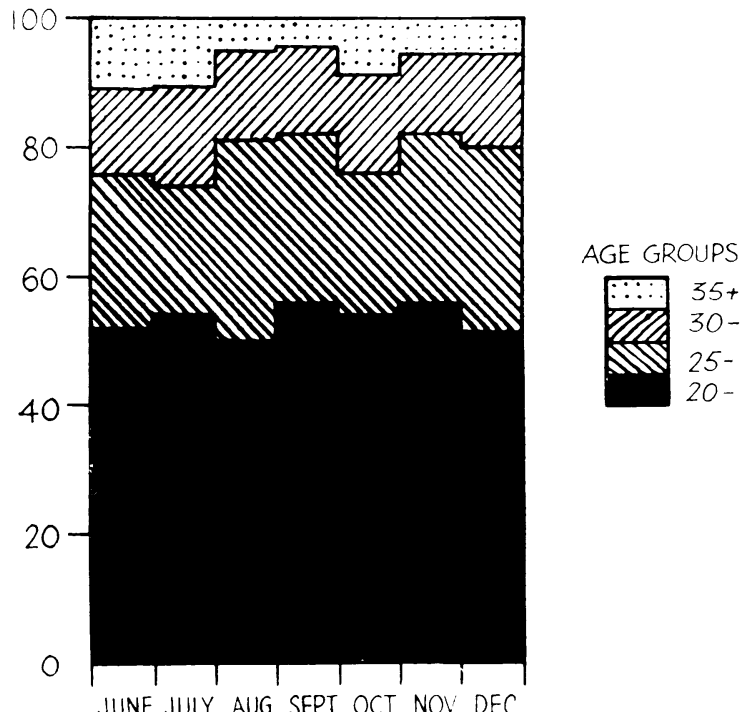

Fici. 2.-Proportional age-distribution of cases throughout the epidemic.

(Fig. 2). Fig. 3 shows the experience of three main reinforcement classes: (i) Groups 7 and under had arrived in the theatre before the major epidemic of 1942: (ii) Group

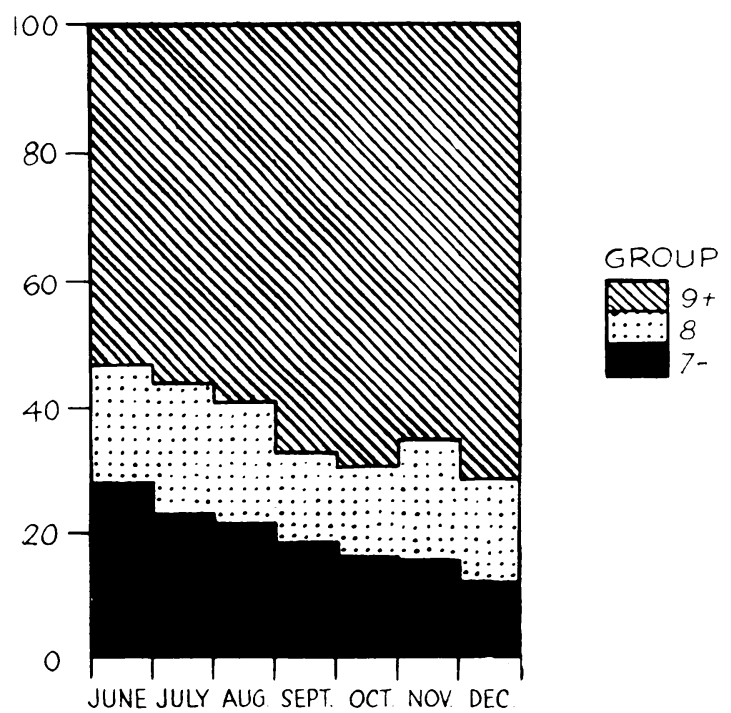

FIG. 3.-Proportional distribution of reinforcement groups throughout the epidemic. 
8 arrived after the end of the 1942 epidemic and had been exposed to the minor winter epidemic of 1943-4, with its peak in January; (iii) Group 9 arrived after both epidemics referred to above, and had therefore no previous experience of large-scale exposure to infection.

We are thus in a position to record a human group situation comparable to an artificial set-up of Greenwood, Topley, and their collaborators (1936) in laboratory observations on mouse epidemics. They found that the newest immigrants to an infected herd were most susceptible at the beginning of an epidemic. The data exhibited in Fig. 3 show that the earliest reinforcement group makes its highest proportionate contribution to total incidence at the beginning of the major epidemic of late 1944. Thereafter its proportionate contribution consistently declines. The newest immigrant group exhibits a reverse trend-i.e., increasing proportionate contribution to total incidence as the epidemic spreads and declines.

This feature of the major epidemic of 1944 prompts a comparison of incidence in the three main reinforcement groups; but differences with respect to the age structure of the groups themselves call for an assessment of liability to infection at different ages as a necessary preliminary to valid comparison. Happily, available data make it possible to relate incidence to the population at risk in different age groups, and hence to estimate age-specific rates as a basis for standardization in what follows.

TABLE III

Age-Specific Rates (1944 Major Epidemic)

\begin{tabular}{|c|c|c|c|c|c|}
\hline \multicolumn{3}{|c|}{ Age } & Population & Cases & Specific Rate (\%) \\
\hline $\begin{array}{l}\text { Under } 22 \\
22 \quad \ldots \\
23 \quad \ldots \\
24 \quad \cdots \\
25-29 \\
30-34 \\
35-39 \\
\text { Over } 39\end{array}$ & $\begin{array}{l}\ldots \\
\cdots \\
\cdots \\
\ldots \\
\cdots \\
\ldots\end{array}$ & $\begin{array}{l}. \\
\ldots \\
\ldots \\
\ldots \\
\ldots \\
\ldots \\
\ldots\end{array}$ & $\begin{array}{r}793 \\
2,113 \\
1,870 \\
1,697 \\
5,661 \\
3,538 \\
1,864 \\
550\end{array}$ & $\begin{array}{r}200 \\
420 \\
301 \\
224 \\
530 \\
281 \\
111 \\
26\end{array}$ & $\begin{array}{r}25 \cdot 2 \\
19 \cdot 9 \\
16 \cdot 1 \\
13 \cdot 2 \\
9 \cdot 4 \\
7 \cdot 9 \\
6 \cdot 0 \\
4 \cdot 7\end{array}$ \\
\hline Total .. & $\cdots$ & .. & 18,086 & 2,093 & $11 \cdot 6$ \\
\hline
\end{tabular}

The relation between incidence and age shown in Table III tallies closely with the distribution given by Hogben and Johnstone (1945). Table IV shows corresponding specific rates of four major age groups separately for the three main reinforcement groups. 
TABLE IV

Age-Specific Rates by Length of Service in the Mediterranean Zone

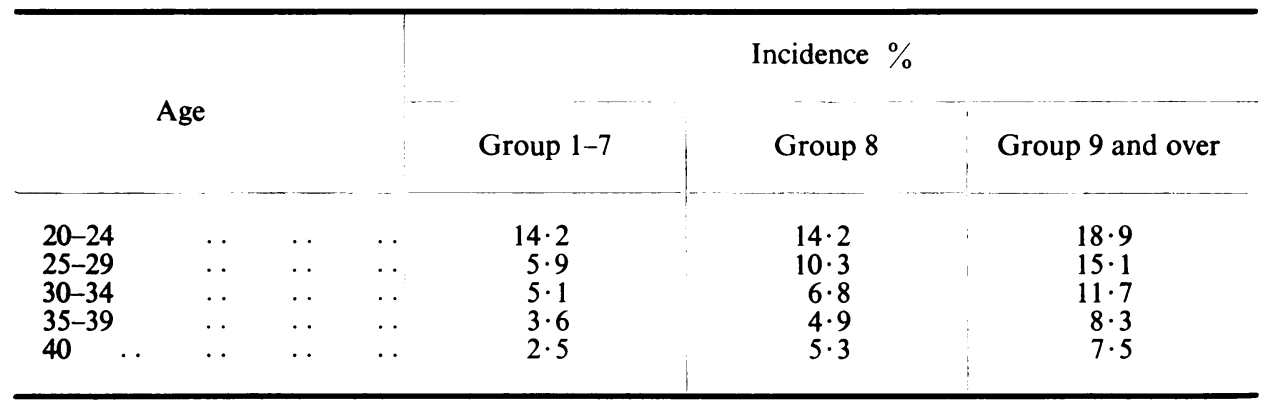

With these data at our disposal we can compute age-standardized rates separately for the three main reinforcement groups as in Table V and Fig. 4.

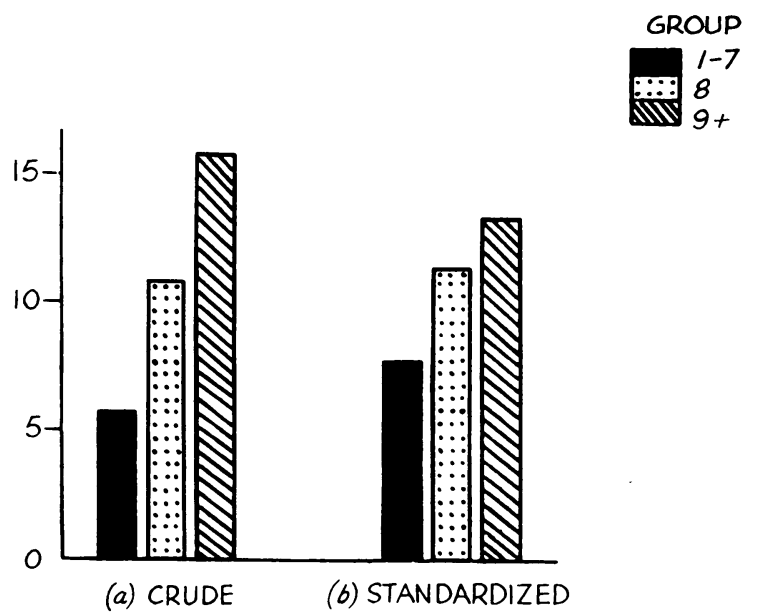

FIG. 4.-Incidence rates in the three reinforcement groups. (a) Crude. (b) Age-standardized.

TABLE V

INCIDENCE IN MAIN ReINFoRCement Groups

\begin{tabular}{|c|c|c|c|c|c|}
\hline & & \multicolumn{2}{|c|}{ Rate per cent. } & \multicolumn{2}{|c|}{ Relative to Groups 1-7 } \\
\hline & & Crude & Standardized & Crude & Standardized \\
\hline $\begin{array}{l}\text { Groups 1-7 } \\
\text { Group 8 } \\
\text { Group 9+ }\end{array}$ & $\begin{array}{l}\ldots \\
\ldots \\
\ldots\end{array}$ & $\begin{array}{r}5 \cdot 67 \\
10 \cdot 87 \\
15 \cdot 79\end{array}$ & $\begin{array}{r}7 \cdot 66 \\
11 \cdot 22 \\
13 \cdot 31\end{array}$ & $\begin{array}{l}100 \\
190 \\
278\end{array}$ & $\begin{array}{l}100 \\
146 \\
174\end{array}$ \\
\hline
\end{tabular}


Since the newest arrivals included a higher proportion of younger personnel, age standardization reduces differences with regard to incidence in the three groups, but standardized and crude rates in Table $V$ tally in so far as they show that the groups most exposed to previous infection had the lowest and the group least exposed to previous infection had the highest infection in the major epidemic of 1944. Of itself this furnishes evidence for the view that an attack of infective hepatitis confers an appreciable measure of immunity. This conclusion receives additional support from the age distribution shown in Table III, for reasons discussed at length by Hogben and Johnstone (op. cit.). On the other hand, the difference exhibited in Table IV offers no evident clue to the phenomenon disclosed in Fig. 3.

It is thus clear that we have to undertake any comparison between units or intradivisional groups with due regard both to age and to length of service in an overseas theatre where the disease is prevalent. We may use the data in Table IV as a basis for computing appropriate correction factors for the crude rates of

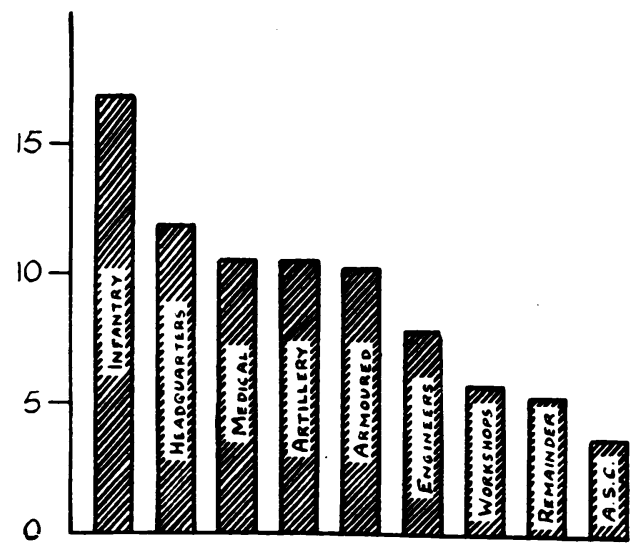

(a) CRUDE RATES

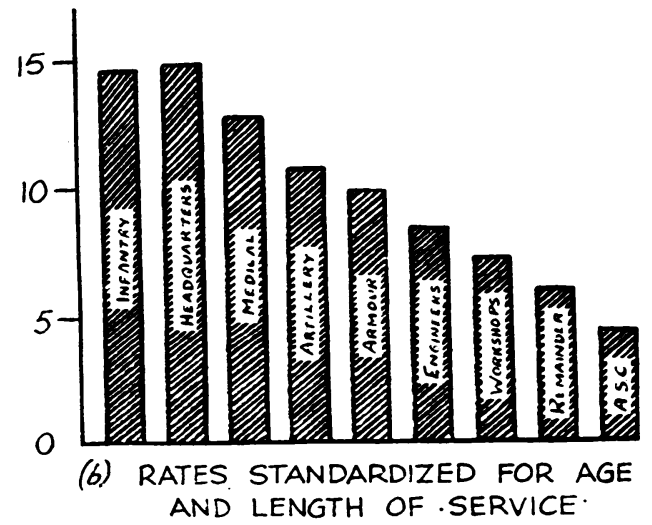

FIG. 5.-Incidence rates in Divisional groups. 
incidence in different arms of the service as shown in Table VI. Such corrections do not greatly modify the picture which emerges from the crude rates themselves. Fig. 5 exhibits such differentials in respect of arm of Service; but we are unable to point to circumstances or habits of life peculiar to those groups with highest or

TABLE VI

\begin{tabular}{|c|c|c|c|c|c|c|c|}
\hline & & & & & & \multicolumn{2}{|c|}{ Incidence $\%$} \\
\hline & & & & & & Crude & $\begin{array}{c}\text { Standardized w.r.t. length } \\
\text { of Service and Age }\end{array}$ \\
\hline Infantry & $\ldots$ & $\ldots$ & $\ldots$ & 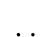 & $\ldots$ & $16 \cdot 9$ & $14 \cdot 7$ \\
\hline Armoured & $\because$ & $\ldots$ & $\because$ & . & $\because$. & $10 \cdot 3$ & $\begin{array}{r}14.7 \\
9.9\end{array}$ \\
\hline Engineers & $\therefore$ & $\ldots$ & $\therefore$ & .. & $\ldots$ & $7 \cdot 8$ & $8 \cdot 3$ \\
\hline Artillery & . & $\therefore$ & $\therefore$ & $\therefore$ & .. & $10 \cdot 6$ & $10 \cdot 6$ \\
\hline Medical & $\because$. & $\ldots$ & 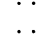 & $\because$ & $\ldots$ & 10.6 & 12.6 \\
\hline Workshops & . & .. & .. & .. & .. & $5 \cdot 7$ & $7 \cdot 1$ \\
\hline H.Q.s & . & . &.. & $\therefore$ & $\therefore$ & 11.9 & $14 \cdot 8$ \\
\hline A.S.C. & $\ldots$ & $\ldots$ & $\ldots$ & $\ldots$ & $\ldots$ & $3 \cdot 7$ & $4 \cdot 4$ \\
\hline Others & . & $\ldots$ &. & .. & $\ldots$ & $5 \cdot 4$ & 6.0 \\
\hline All .. & .. & .. & . & .. & .. & $11 \cdot 6$ & - \\
\hline
\end{tabular}

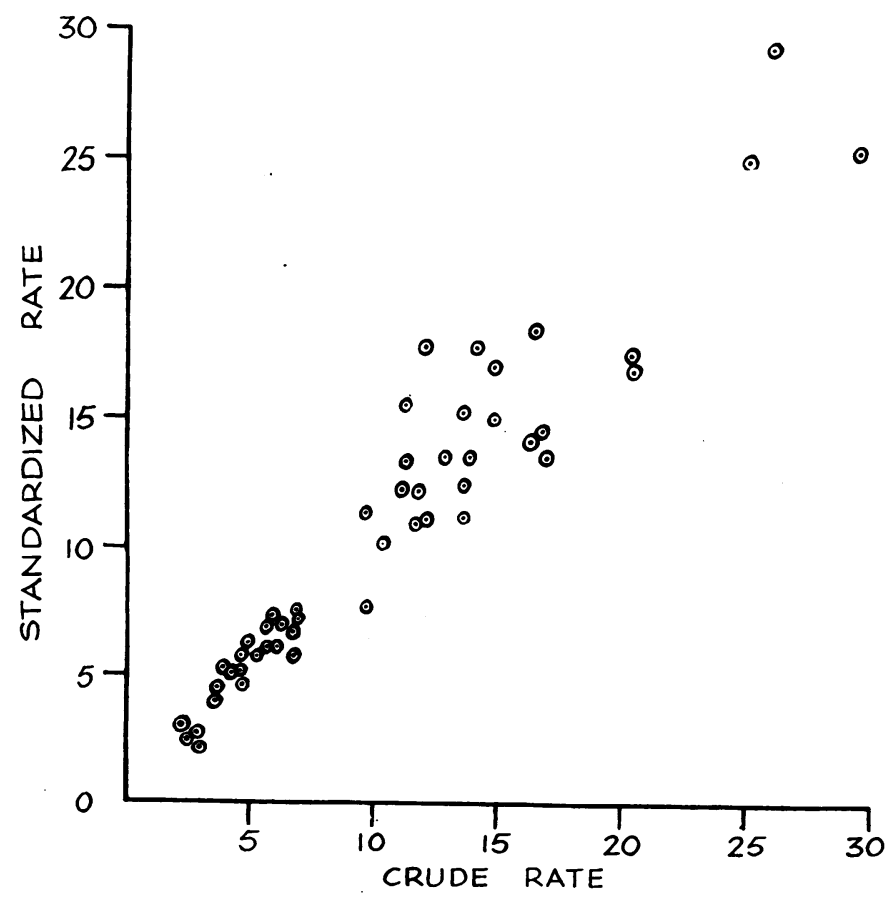

Fig. 6. - Correlation between crude and standardized rates for infective hepatitis. 
lowest rates. All that we are entitled to say is that the serial order reveals no positive evidence for droplet spread as the prevalent mode of transmission.

It was also possible to make an exhaustive comparison of individual units of the division as an alternative framework of environmental differences with a view to seeking clues relevant to the aetiology of the disease. One positive result of

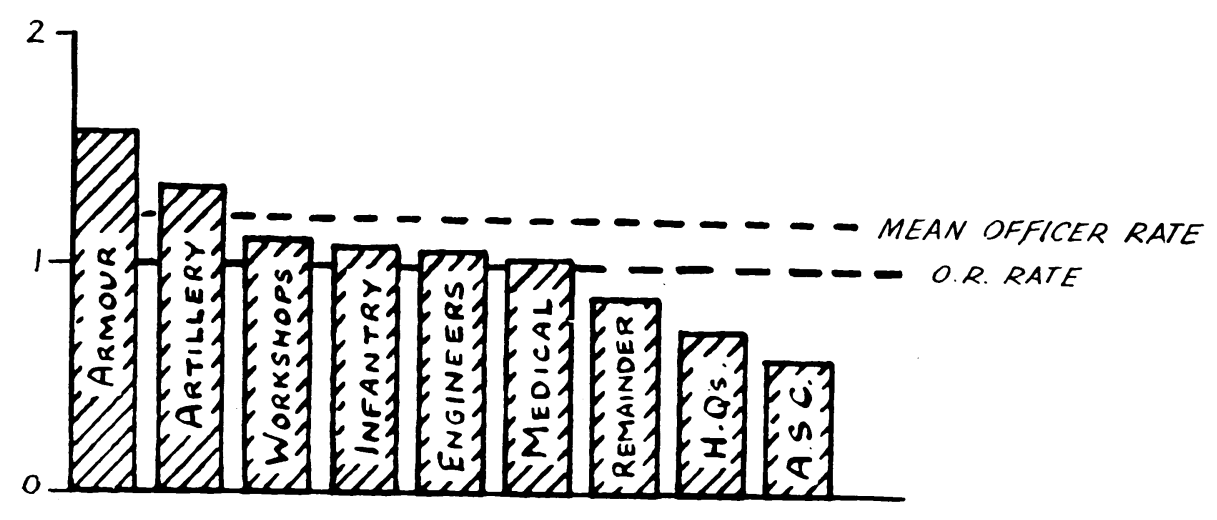

(a) CRUDE RATES

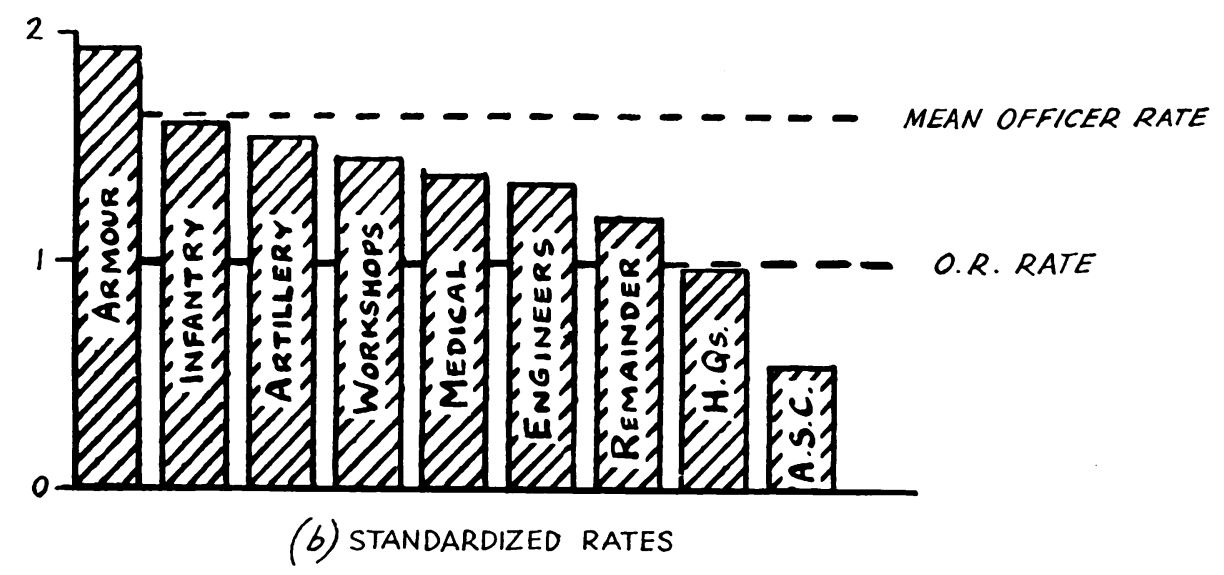

FIG. 7.-Showing the ratio of incidence rates for officers: O.R.s.

this comparison is worthy of comment. Among infantry battalions, ${ }^{*}$ the only exclusively Maori unit had a standardized incidence of $2 \cdot 4$-far below the lower limit of 14.6 for others. In view of the lack of data for applying appropriate correction factors to a comparable breakdown of Canadian troops (vide infra) it is important to record the very close correspondence of the standardized and crude rates for individual units of the whole division. Fig. 6 shows the scatter diagram. The value of $r$ was 0.96 .

\footnotetext{
800 men.

A representative figure for the size of an infantry battalion not subject to gross variation is
} 
A differential statistic which attracted attention at an early stage of the war is the excessive incidence of infective hepatitis among British officers. Incidence among British officers in the Mediterranean zone has been about four times as high as among other ranks. In the New Zealand division the differential is far less striking. The crude New Zealand officer rate in the major epidemic of 1944 was only $21 \%$ higher than the rate for O.R.s, and, even when standardized with respect to age and length of service, it exceeds that of O.R.s by only $62 \%$. Fig. 7 shows the variation of the Officer-O.R. differential according to arm of Service. On the whole, the differential is less striking in rear than in forward units.

A comparison between the differentials discussed above in respect of infective hepatitis and other major diseases of known aetiology does not disclose any correspondence sufficiently firm to justify tabulation of the results in this context. Available information also made it possible to explore the relation of severity to age, length of service in the zone, and date of onset vis-à-vis the course of the late 1944 epidemic. The most manageable yardstick for this purpose is duration of stay in hospital. Administrative difficulties connected with evacuation of severe cases made it inadvisable to attempt estimation of mean figures. Accordingly, the basis of comparison in Table VII is the percentage of cases remaining in hospital for more than 70 and more than 80 days. Separation of the data with regard to age and reinforcement group shows that $(a)$ among new arrivals severity increases with increasing age; (b) among seasoned troops severity is not conspicuously dependent on age.

TABLE VII

Percentage Frequency by Age and Reinforcement Group of Cases lasting(1) 70 days and over:

\begin{tabular}{|c|c|c|c|c|}
\hline & & Group 1-7 & Group 8 & Group $9+$ \\
\hline $\begin{array}{ll}20- & . \\
25- & . \\
30- & . \\
35- & . \\
40+ & .\end{array}$ & $\begin{array}{l}. \\
\cdots \\
\cdots \\
\cdots \\
\cdots\end{array}$ & $\begin{array}{l}20 \cdot 00 \\
14 \cdot 50 \\
23 \cdot 08 \\
12 \cdot 90 \\
10 \cdot 00\end{array}$ & $\begin{array}{l}17 \cdot 82 \\
23 \cdot 96 \\
29 \cdot 41 \\
23 \cdot 08 \\
50 \cdot 00\end{array}$ & $\begin{array}{l}17 \cdot 35 \\
18 \cdot 11 \\
31 \cdot 48 \\
30 \cdot 56 \\
64 \cdot 29\end{array}$ \\
\hline Total . & . & $16 \cdot 98$ & $21 \cdot 20$ & $20 \cdot 27$ \\
\hline \multicolumn{5}{|c|}{ (2) 80 days and over: } \\
\hline $\begin{array}{ll}20- & . \\
25- & . \\
30- & . \\
35- & . \\
40+ & .\end{array}$ & $\begin{array}{l}. \\
\cdots \\
\cdots \\
\cdots \\
.\end{array}$ & $\begin{array}{l}13 \cdot 33 \\
10 \cdot 50 \\
14 \cdot 29 \\
12 \cdot 90 \\
10 \cdot 00\end{array}$ & $\begin{array}{l}10 \cdot 89 \\
17 \cdot 71 \\
20 \cdot 59 \\
23 \cdot 08 \\
25 \cdot 00\end{array}$ & $\begin{array}{l}10 \cdot 34 \\
14 \cdot 57 \\
17 \cdot 90 \\
20 \cdot 83 \\
50 \cdot 00\end{array}$ \\
\hline Total & . & $11 \cdot 94$ & $14 \cdot 33$ & $12 \cdot 92$ \\
\hline
\end{tabular}


Evidence to the effect that a previous attack of infective hepatitis confers an appreciable measure of immunity to subsequent infection suggests a possible explanation of this contrast. It may well be that a previous attack which fails to confer complete immunity at least ensures that a subsequent attack will be mild.

The next table (Table VIII) indicates that for the late 1944 epidemic the severity of the disease was least at the beginning of the epidemic.

TABLE VIII

Percentage Frequency of Severe Cases in each Reinforcement Group at Different PERIODS THROUghout THE EPIDEMIC

\begin{tabular}{|c|c|c|c|c|c|c|}
\hline & \multicolumn{3}{|c|}{70 Days and Over } & \multicolumn{3}{|c|}{80 Days and Over } \\
\hline & June- & Sept.- & Nov.- & June- & Sept.- & Nov.- \\
\hline $\begin{array}{l}\text { Group 1-7 } \\
\text { Group } 8 \\
\text { Group 9+ }\end{array}$ & $\begin{array}{l}13 \cdot 73 \\
16 \cdot 85 \\
14 \cdot 73\end{array}$ & $\begin{array}{l}20 \cdot 83 \\
22 \cdot 09 \\
20 \cdot 74\end{array}$ & $\begin{array}{l}12 \cdot 05 \\
23 \cdot 71 \\
23 \cdot 25\end{array}$ & $\begin{array}{r}7 \cdot 84 \\
11 \cdot 24 \\
9 \cdot 69\end{array}$ & $\begin{array}{l}15 \cdot 62 \\
15 \cdot 34 \\
12 \cdot 60\end{array}$ & $\begin{array}{r}8 \cdot 43 \\
15 \cdot 46 \\
15 \cdot 97\end{array}$ \\
\hline Total .. & $14 \cdot 92$ & $20 \cdot 95$ & $21 \cdot 60$ & $9 \cdot 58$ & $13 \cdot 50$ & $14 \cdot 71$ \\
\hline
\end{tabular}

Infective Hepatitis among Canadian Troops in C.M.F.

Canadian troops selected for study were the First Corps, composed of: (a) an infantry division which had experienced a major epidemic during the previous season in the zone; $(b)$ an armoured division which had arrived in the zone late in the previous epidemic season (winter, 1943-4) without itself experiencing a high rate of infection; $(c)$ Corps troops, including units which arrived with the infantry and units which arrived with the armoured division.

Some additional data were obtained regarding base units. It was impracticable to obtain final hospital diagnoses for the sample as a whole. Hence such as follow refer to diagnoses made at field ambulance level or at casualty clearing stations. A pilot survey showed that error arising from this defect of documentation is trivial. A partial census planned to furnish basic data for standardizing crude rates had to be abandoned for operational reasons.

Fig. 8 shows the epidemiological picture for the two divisions mentioned above during the period August, 1943, to December, 1944. Two features prompt comment:

(i) The earlier arrivals (infantry division) suffered considerably less in the second (late 1944) epidemic period than in the earlier one.

(ii) The new arrivals who suffered heavily in the second epidemic season remained comparatively free from the disease during the later stages of the first epidemic, and that although sporadic cases occurred in all units of the division. 
The first conclusion stated above calls for no further comment in view of its consistency with data recorded above for N.Z. troops. On its own merits, the second admits of more than one possible explanation, inter alia: $(a)$ the virulence

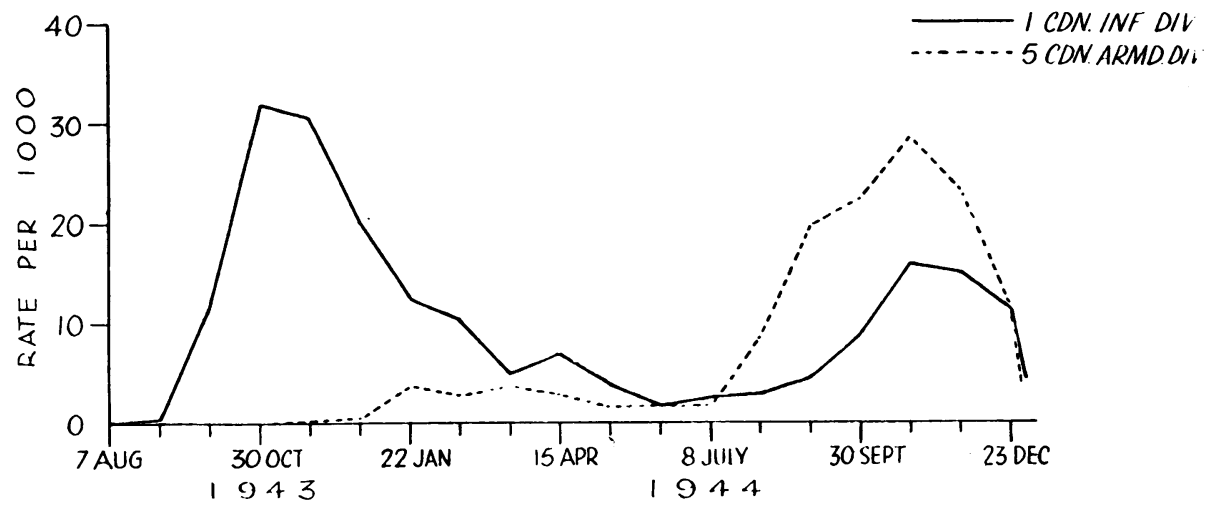

FIG. 8.-Showing incidence of infective hepatitis in $1 \mathrm{Cdn}$. Inf. Div. and $5 \mathrm{Cdn}$. Armd. Div. from time of arrival in C.M.F. until Dec. 30th, 1944 (in 4-weekly periods).

of the disease had fallen off considerably in the later stages of the epidemic; $(b)$ the armoured division reached the zone at a time when conditions were not propitious to spread of the disease; $(c)$ it was not engaged in active fighting like the infantry division which succumbed to the first epidemic or as were both the divisions during the second epidemic, and hence was more resistant than at a later date.

Against $(c)$ we must set the fact that base troops stationed in the same area as the armoured division suffered heavily during the 1943-4 outbreak. We have no certain means of discriminating between $(a)$ and $(b)$ from data at our disposal.

Table IX makes possible a comparison of rates among base and forward troops during the second epidemic, when the former suffered relatively little, though situated in circumstances more favourable to droplet infection than were forward troops living largely in the open. Even within a division this difference with respect to prevalence of the disease among forward and rear troops still holds good,

TABLE IX

InCidence of Infective Hepatitis in Various Groups of Canadian Troops in C.M.F. DURing Period July 1St to Dec. 23Rd, 1944

\begin{tabular}{|c|c|c|}
\hline & $\begin{array}{c}\text { Population } \\
\text { (Average Strength for Period) }\end{array}$ & $\begin{array}{l}\text { Infective Hepatitis } \\
\text { (Rate per 1,000) }\end{array}$ \\
\hline $\begin{array}{l}\text { 5th Armoured Division } \\
\text { 1st Infantry Division } \\
\text { Corps Troops } \\
\text { Base Troops at Avellino }\end{array}$ & $\begin{array}{r}17,710 \\
17,260 \\
10,990 \\
2,005\end{array}$ & $\begin{array}{r}113 \cdot 10 \\
61 \cdot 06 \\
35 \cdot 95 \\
13 \cdot 9\end{array}$ \\
\hline
\end{tabular}


as shown by the breakdown in Fig. 9, which exhibits monthly rates separately for Infantry, Artillery, and Services. In view of considerations advanced previously it is unlikely that the great excess of incidence among Infantry would disappear if data were available for age standardization. We might expect that units heavily affected during the first epidemic would be relatively immune to the second.

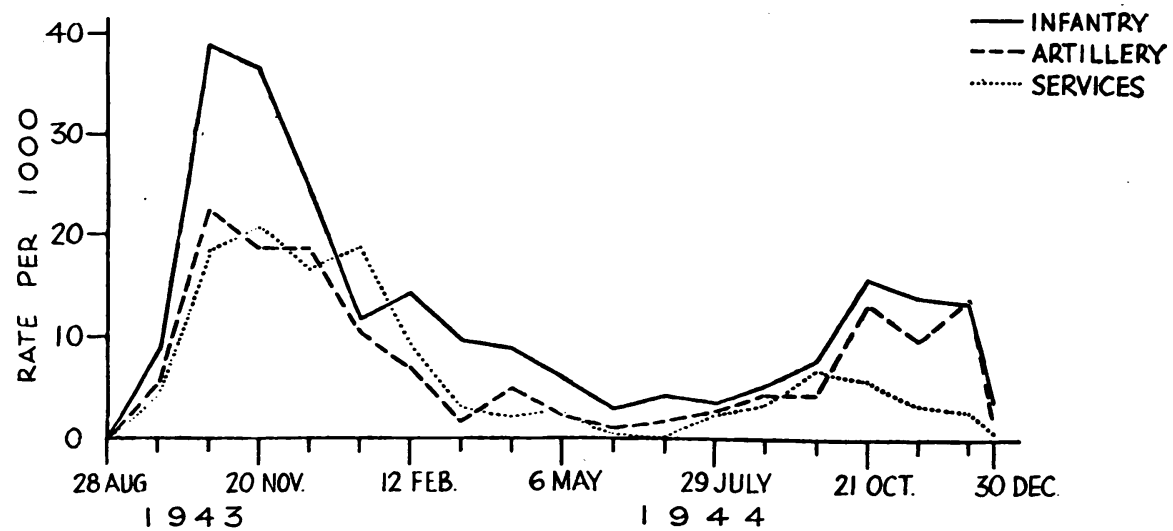

FIG. 9.-Showing the incidence of infective hepatitis in three main groups of $1 \mathrm{Cdn}$. Div. (in 4-weekly periods).

Analysis of unit rates from August, 1943, to December, 1944 failed to confirm this expectation. Comparison of such rates with rates for other diseases failed to disclose any suggestive similarities. A spurious correlation emerges in any Army statistics of this sort, on account of the fact that certain arms, more especially Infantry, have excessive incidence of all major sources of wastage.

\section{Concomitant Incidence in the Civil Population}

Lieut.-Col. Miles, Chief of the Public Health Department, Allied Commission, Southern Region, kindly obtained for us information from medici provinciali (comparable to M.Os.H.) regarding eleven of the fifteen provinces which make up the region occupied by the autumn and winter of 1943, when Allied forces experienced an epidemic affecting all classes of troops. The medici provinciali were instructed: $(a)$ to ascertain from all hospitals and doctors the number of cases of catarrhal jaundice during the period October, 1943, to February, 1944; (b) to make catarrhal jaundice a notifiable disease during the autumn and winter, 1944-5, and to report all cases through the normal 10-day and monthly returns of notifiable disease to the Public Health Department of Allied Commission.

Table $\mathrm{X}$ summarizes the outcome. During neither period was any large outbreak reported. During the 1943-4 period the largest was at Taranto, where 24 cases were reported anong Italian military personnel. There is thus a striking contrast between the few cases among the civilian population and the widespread 
occurrence of the disease among Allied troops of the same region in the winter, $1943-4$.

TABLE $\mathrm{X}$

Cases of Catarrhal Jaundice reported by 11 Provinces of Southern Region, Italy

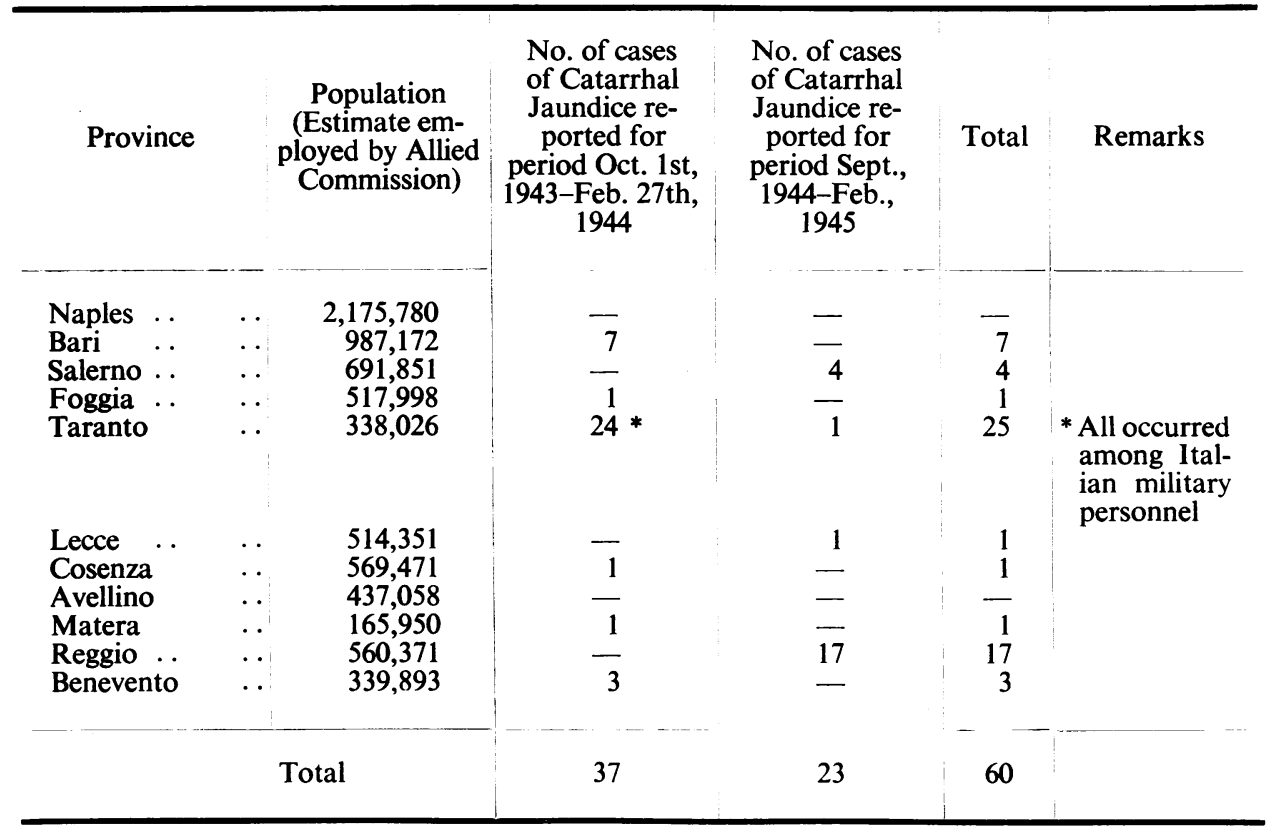

Troops of the Eighth Army entered the Northern Province of Forli in August, 1944. The force included the 1st Canadian Corps and 2nd N.Z. Division-two formations in which infective hepatitis was epidemic. These formations remained in the province until February, 1945, except for a rest period of the N.Z. troops during November, 1944. At our request Lieut.-Col. Snedeker, A.M.G., Medical Officer of Emilia Region, made catarrhal jaundice notifiable throughout the province for the period November, 1944, to January, 1945, inclusive. Once again, only trivial outbreaks were reported. Without claiming high reliability for these findings, we can safely conclude that no large-scale outbreak occurred among Italian civilians when Allied troops in the same regions experienced major epidemics. On the other hand, reports of frequent cases of infective hepatitis among Italian prisoners of war in the Western Desert are authentic (Spooner, 1943).

\section{Concomitant Occurrence of Jaundice among Syphilitics}

One of the outstanding problems of war medicine has been an inordinately high incidence of jaundice among syphilitics. When this inquiry began evidence was 
accumulating in favour of the view that such jaundice is an infection spread by syringes employed for intravenous arsenotherapy, and it was a widespread belief that the icterogenic agent is identical with the virus of infective hepatitis. We therefore sought information concerning a relation between the two conditions. Brig. Lees, Consulting Venereologist, A.F.H.Q., kindly arranged for the circulation of a questionnaire to supply the following data for all syphilitics under arsenic treatment in V.D. clinics to the end of December, 1944:

Personal number; rank; name; age; date of coming to Mediterranean zone (including Persia and Iraq); date of commencing arsenical treatment for syphilis; attacks of jaundice prior to treatment (with dates of occurrence); jaundice during treatment (with dates).

The results were as follows:

(a) The total number of patients for whom particulars were received was 872 . For the vast majority of these the information was in all respects complete.

(b) The number of patients who developed jaundice at any time during treatment was 316-an over-all incidence of $36 \cdot 24 \%$.

(c) The relation of age to liability (Table XI) contrasts sharply with previous findings with respect to infective hepatitis (Table III). The contrast is entirely consonant with the conclusion of Hogben and Johnstone (op. cit.), who drew their data from the experience of troops in Britain.

TABLE XI

Showing Age-Distribution of Patients with and without Post-Arsphenamine Jaundice aNd INCIDENCE Rates IN Age-Groups

\begin{tabular}{|c|c|c|c|c|}
\hline \multicolumn{2}{|c|}{ Age-Group } & $\begin{array}{l}\text { Total Numbers in } \\
\text { Each Group }\end{array}$ & $\begin{array}{c}\text { Numbers with } \\
\text { Jaundice }\end{array}$ & $\begin{array}{l}\text { Percentage with } \\
\text { Jaundice }\end{array}$ \\
\hline $\begin{array}{ll}18- & \ldots \\
21- & \ldots \\
26- & \ldots \\
31- & \ldots \\
36- & \ldots \\
40+ & \ldots \\
\text { Unrecorded }\end{array}$ & $\begin{array}{l}\cdots \\
\cdots \\
\cdots \\
\cdots \\
\cdots\end{array}$ & $\begin{array}{r}16 \\
319 \\
245 \\
164 \\
88 \\
35 \\
5\end{array}$ & $\begin{array}{r}4 \\
116 \\
100 \\
55 \\
30 \\
10 \\
1\end{array}$ & $\begin{array}{c}25 \cdot 00 \\
36 \cdot 36 \\
40 \cdot 82 \\
33 \cdot 54 \\
34 \cdot 09 \\
28 \cdot 57 \\
-\end{array}$ \\
\hline Totals & .. & 872 & 316 & $36 \cdot 24$ \\
\hline
\end{tabular}

(d) Unlike infective hepatitis, post-arsphenamine jaundice shows no welldefined seasonal swing.

(e) Although the real incubation period may be shorter, we here follow the practice of previous writers who have employed the term to represent the timeinterval between beginning of treatment and development of jaundice. For the 
whole series (Fig. 10) the mean value, 168 days, is higher than that usually quoted. The approximate modal value is 104 days. There are, however, great individual differences, the range being from 9 days to as much as 872 days, the coefficient of variation being $62 \%$. Of the total cases, $82 \%$ occur during the first 225 days of treatment, and $64 \%$ are concentrated in the 120 days between 76 and 195 days from commencement of treatment. The period is unaffected by differences of age and of season when treatment started. Thus the mean values for ages under 25, 26-30, and 36 and over are respectively 169, 171, and 152 days-differences which are of no statistical significance. For patients starting treatment during the four quarters of the year the means are: for January-March inclusive, 183 days; April-June, 154 days; July-September, 153 days; October-December, 172 days. None of these differs substantially from the general average irrespective of season. Although precise delimitation of the incubation period of post-arsphenamine jaundice on the basis of these data is impossible, they strongly suggest that it is significantly longer than that of infective hepatitis (21-35 days).

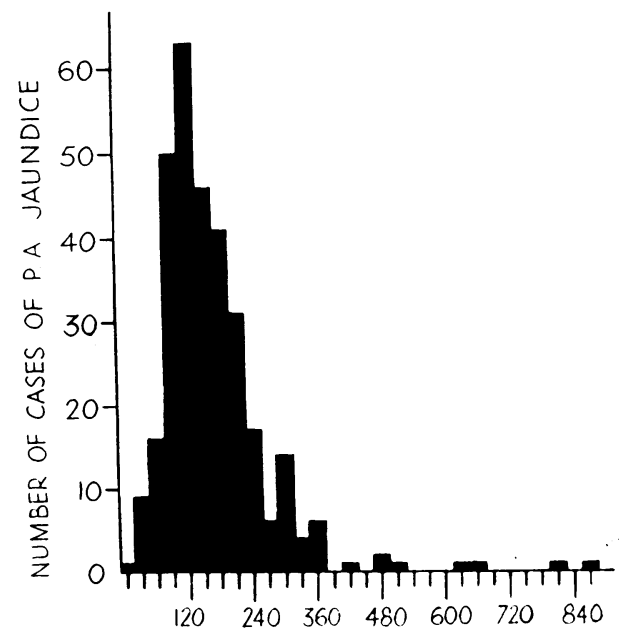

FIG. 10.-Showing the frequency distribution of the " incubation period " of post-arsphenamine jaundice.

( $f$ ) As regards relation of occurrence of post-arsphenamine jaundice to prior history of infective hepatitis, Table XII summarizes relevant data. Of the total, $35(4.01 \%)$ had a history of jaundice before arsenical treatment. Of these, $12(34 \cdot 29 \%)$ developed jaundice during treatment, as compared with $304(36 \cdot 32 \%)$ of the remaining 837 with no such history. The difference is of no statistical significance. Thus a previous attack of infective hepatitis had no influence on liability to post-arsphenamine jaundice. 
TABLE XII

Showing the Liability to Post-Arsphenamine Jaundice in Relation to prior History of INFECTIVE HEPATITIS

\begin{tabular}{|c|c|c|c|}
\hline & $\begin{array}{l}\text { Number in } \\
\text { Group }\end{array}$ & $\begin{array}{l}\text { Number Developing } \\
\text { Jaundice During } \\
\text { Treatment }\end{array}$ & $\begin{array}{l}\text { Percentage Incidence } \\
\text { of Jaundice During } \\
\text { Treatment }\end{array}$ \\
\hline $\begin{array}{l}\text { Patients with prior attack of infective } \\
\text { hepatitis }\end{array}$ & 35 & 12 & $34 \cdot 29$ \\
\hline tive hepatitis & 837 & 304 & $36 \cdot 32$ \\
\hline Total & 872 & 316 & $36 \cdot 24$ \\
\hline
\end{tabular}

All the results of this part of the inquiry converge to the conclusion that the presumptive agent of jaundice accompanying syphilis treatment is not identical with the virus of infective hepatitis.

\section{SUMMARY}

1. This communication presents data bearing on epidemiological features of infective hepatitis and post-arsphenamine jaundice among Allied troops and the indigenous civil population in Italy during the late 1944 epidemic season.

2. Infective hepatitis displays striking seasonal variations, incidence being highest in autumn and winter and lowest in spring and summer.

3. Age exerts great influence on liability to infective hepatitis. Within the age limits of an Army population, liability decreases progressively with increasing age.

4. A group which has passed through a major epidemic of infective hepatitis is less susceptible than a group which has not.

5. Age-standardized incidence rates show that officers are more susceptible to infective hepatitis than other ranks.

6. Incidence differs considerably in the various arms of the Service in a division. Since forward troops are much more susceptible than base troops, droplet spread would not appear to be the most important method of transmission in major epidemics.

7. Though Italian troops suffered heavily from the disease in the Western Desert in 1942, the Italian civil population appears to have been free from any large-scale outbreak while Allied troops were experiencing major epidemics of infective hepatitis.

8. The epidemiological features of post-arsphenamine jaundice are in sharp contrast to those of infective hepatitis. Liability to post-arsphenamine jaundice is not influenced by age. It is subject to no striking seasonal variation. The 
time of onset suggests a prolonged incubation period of about 100 days; and previous attacks of infective hepatitis confers no immunity. The icterogenic agent of post-arsephenamine jaundice is not the virus of infective hepatitis.

We wish to acknowledge in particular the assistance and co-operation of Brig. Kendrick, D.M.S., 2nd N.Z.E.F.; Col. King, A.D.M.S., 2nd N.Z. Division; Brig. Sinclair, D.D.M.S., 1st Canadian Corps; and Brig. Lees, Consulting Venereologist, A.F.H.Q. We also received assistance from many other medical and non-medical officers who are unfortunately too numerous for us to thank individually.

The inquiry on which this article is based was carried out under the auspices of Brig. F. A. E. Crew, Director of Biological Research, War Office.

We wish to thank Lieut.-Gen. Sir Alexander Hood, Director-General, Army Medical Services, for permission to publish.

\section{REFERENCES}

Greenwood, M., Bradford Hill, A., Topley, W. W. C., and Wilson, J. (1936). Med. Res. Cncl. Sp. Rep. Ser., No. 209, London.

Spooner, E. T. C. (1943). Proc. roy. Soc. Med., 37, 165.

Hogben, L., and Johnstone, M. M. (1945). Bull. Army Health Statistics, 1st Series, 10th issue. 